\title{
Seasonal and Spatial Distribution of Phytoplankton in the Waters off Nuclear Power Plants, North of Taiwan
}

\author{
Wen-Tseng Lo \\ Associate Professor, Institute of Marine Resource, National Sun Yat-sen University, Kaohsiung, Taiwan 804, R.O.C., \\ lowen@mail.nsysu.edu.tw \\ Jiuan-Jiuan Hwang \\ Lecturer, Department of Aquaculture, National Kaohsiung Marine University, Kaohsiung, Taiwan 811, R.O.C. \\ Pei-Kai Hsu \\ Graduate Student, Institute of Marine Resource, National Sun Yat-sen University, Kaohsiung, Taiwan 804, R.O.C. \\ Hung-Yen Hsieh \\ Graduate Student, Institute of Marine Resource, National Sun Yat-sen University, Kaohsiung, Taiwan 804, R. O.C. \\ Yueh-Yuan Tu \\ Director, Department of Industrial Safety and Environmental Protection, Taiwan Power Company, Taipei, Taiwan 106, \\ R.O.C.
}

See next page for additional authors

Follow this and additional works at: https://jmstt.ntou.edu.tw/journal

Part of the Terrestrial and Aquatic Ecology Commons

\section{Recommended Citation}

Lo, Wen-Tseng; Hwang, Jiuan-Jiuan; Hsu, Pei-Kai; Hsieh, Hung-Yen; Tu, Yueh-Yuan; Fang, Tien-Hsi; and Hwang, JiangShiou (2004) "Seasonal and Spatial Distribution of Phytoplankton in the Waters off Nuclear Power Plants, North of Taiwan," Journal of Marine Science and Technology. Vol. 12: Iss. 5, Article 3.

DOI: $10.51400 / 2709-6998.2258$

Available at: https://jmstt.ntou.edu.tw/journal/vol12/iss5/3

This Research Article is brought to you for free and open access by Journal of Marine Science and Technology. It has been accepted for inclusion in Journal of Marine Science and Technology by an authorized editor of Journal of Marine Science and Technology. 


\section{Seasonal and Spatial Distribution of Phytoplankton in the Waters off Nuclear Power Plants, North of Taiwan}

\section{Acknowledgements}

This research was supported by a grant from the Taiwan Power Company to W. T. Lo. We are grateful for the assistance in the field from the skipper, crew, and technicians of the RV "Ocean Researcher II". We also acknowledge Prof. C.T. Shih for his advice and comments on the manuscript.

\section{Authors}

Wen-Tseng Lo, Jiuan-Jiuan Hwang, Pei-Kai Hsu, Hung-Yen Hsieh, Yueh-Yuan Tu, Tien-Hsi Fang, and JiangShiou Hwang 


\title{
SEASONAL AND SPATIAL DISTRIBUTION OF PHYTOPLANKTON IN THE WATERS OFF NUCLEAR POWER PLANTS, NORTH OF TAIWAN
}

\author{
Wen-Tseng Lo*, Jiuan-Jiuan Hwang**, Pei-Kai Hsu***, Hung-Yen Hsieh***, \\ Yueh-Yuan Tu****, Tien-Hsi Fang*****, and Jiang-Shiou Hwang******
}

Key words: phytoplankton, thermal discharge, nuclear power plant, distribution.

\section{ABSTRACT}

Species composition of phytoplankton was monitored seasonally in the waters off the First and Second Nuclear Power plants (NPP1 and NPP2), north of Taiwan during 2001-2002. In total, 290 phytoplankton samples were collected and 265 taxa of phytoplankton were recorded. Chaetoceros compressus, Pseudo-nitzschia delicatissima, Skeletonema costatum, Thalassionema nitzschioides, and Lauderia annulata were the top five dominant species. Together they comprised $75 \%$ of the total phytoplankton cells. The species number and abundance of phytoplankton showed distinct seasonal, annual, and spatial changes, higher abundance in 2002 than 2001 and highest in August in both years and lowest in March in 2001 and in October in 2002. The highest species number and diversity were found in May 2002, the lowest species number in March 2001, and the lowest diversity in August 2002 that $C$. compressus dominated in the waters of NPP2 and Hwang River. The major dominant species of phytoplankton were similar but ranked differently between seasons and years. The abundance of phytoplankton generally decreased from inshore to offshore waters. The abundance and species number of phytoplankton were usually higher in the waters of NPP1 than that of NPP2 in 2001, but it was reverse in 2002. The effect of seasonal change in temperature on phytoplankton was significant in this study area, the abundance of phytoplankton generally increased with increasing temperature, but showed negative correlations with salinity and nutrients. The local topography and hydrography might play secondary roles to enhance the effect of temperature on phytoplankton, particularly in the waters of NPP2 and during summer.

Paper Submitted 10/16/04, Accepted 01/25/05. Author for Correspondence: Wen-Tseng Lo.E-mail: lowen@mail.nsysu.edu.tw.

*Associate Professor, Institute of Marine Resource, National Sun Yat-sen University, Kaohsiung, Taiwan 804, R.O.C.

**Lecturer, Department of Aquaculture, National Kaohsiung Marine University, Kaohsiung, Taiwan 811, R.O.C.

*** Graduate Student, Institute of Marine Resource, National Sun Yat-sen University, Kaohsiung, Taiwan 804, R.O.C.

****Director, Department of Industrial Safety and Environmental Protection, Taiwan Power Company, Taipei, Taiwan 106, R.O.C.

*****Associate Professor, Department of oceanography, National Taiwan Ocean University, Keelung, Taiwan 202, R.O.C.

****** Professor, Institute of Marine Biology, National Taiwan Ocean University, Keelung, Taiwan 202, R.O.C.

\section{INTRODUCTION}

Phytoplankton plays the role of primary producer in the marine food chain. They can convert inorganic material, such as nitrate and phosphate, into new organic compounds (e.g., lipids and proteins) through photosynthesis. It is also known to be the food source for herbivorous zooplankton, and thereby usually serves as "bottom up controller" in the marine ecosystem. Most phytoplankton assemblages are characterized as resilience stability, sensitive to environmental changes and having ability to recover their community structure and function quickly after external impacts. However, long-term or great changes of hydrographic condition (e.g., temperature) may induce the succession of phytoplankton assemblages in temporal and spatial scales, and thereby influence the community structure of the higher trophic levels in the ocean (Ingrid et al., 1996; Cottingham, 1999).

In last decades, many countries have been concerned with the impact by power plants, particularly the nuclear power plants, on local ecosystem. They not only undertook long-term environmental impact assessment of power plants but also published their results on journals or websites. For instances, Hungary scientists made a series of environmental assessments of power plants for many years, including hydrology, phytoplankton, zooplankton, and other environmental parameters (Nagy et al., 2001; Ovari et al. 2001). Most power plants are located near river or coastal areas for convenience to intake water for cooling machine and to discharge the warm water. The influence of thermal discharge of power plant on aquatic ecosystem varied in time and space. For instance, the thermal discharge of a power plant in the lower section of Parana River showed no apparent influence on abundance, productivity, and diversity of phytoplankton under sound preventive management (Mercado and Gomez 1999). However, the thermal discharge of some other power plants might cause increase in abundance of phytoplank- 
ton in surrounding waters, and thereby induced the mass occurrence of sessile mussel in the inlet tube and block the passage of the tube. The environmental investigation in the surrounding waters of the nuclear power plants in Finland has been undertaken continuously for 20 years (Ilus et al., 1987; Keskitalo and Ilus, 1987; Ilus et al., 1992; Ikäheimonen et al., 1995). No apparent effect of radiative pollutions on marine organisms was found, and no clear and direct relationships between the thermal discharge of nuclear power plants and eutrophication were detected. However, the thermal discharge of power plants may have significant effect on planktons and other organisms within small or intertidal areas near the plants, and may influence the hydrographic conditions and increase the difficulty of fishery (Sasikumar et al., 1993), particularly with the addition of biotic inhibitor into the intake cooling water (Saravanane et al., 1998).

In this study, we examined seasonal and spatial variations of phytoplankton in relation to environmental variables in the waters off two NPPs of northern Taiwan. We were also concerned about the phytoplankton in the waters near NPPs and evaluated the possible influence of thermal discharge of NPPs on the phytoplankton assemblages.

\section{MATERIALS AND METHODS}

Phytoplankton samples were collected seasonally on board RV 'Ocean Researcher II' from March 2001 to October 2002 in waters off NPP1 and NPP2, northern Taiwan. In total, 42 sampling stations, with 7 transects each including 6 stations from coast $(10 \mathrm{~m}), 250 \mathrm{~m}$, $500 \mathrm{~m}, 1 \mathrm{~km}, 1.5 \mathrm{~km}$, and $2 \mathrm{~km}$ offshore, were established (Fig. 1). Water samples were taken at 1-2 m depth with 5-liter Go-Flo bottles that equipped on the SeaBird CTD-Rosette assembly (General Oceanic). Each $500 \mathrm{~mL}$ water sample was added with $25 \mathrm{~mL}$ of borax-buffered formalin for preservation. Temperature and salinity were also recorded simultaneously at each station. A total of 290 water samples (141 and 149 samples in 2001 and 2002, respectively) were analyzed for phytoplankton. In the laboratory, the preserved sample was shaken for homogeneity and then a $100 \mathrm{~mL}$ sample was concentrated to $1 \mathrm{~mL}$ by sedimentation for 24 hours in a Combined Plate Chamber (Hydro Bios). Phytoplankton cells in the concentrated sample were identified and counted with an inverted microscope (Nikon-A300) at 200 or 400 magnifications, and the species abundance was expressed as cells per liter. Keys and reference books used for identification of the phytoplankton were mainly based on Yamaji (1991) and Chihara and Murano (1997). Identification was carried to species or genus level, and the Shannon diversity index (Shanon and Weaver, 1963) was used to indicate the species diversity at each station. Differences in hydrological variables and phytoplankton abundance in the waters of NPP1 and NPP2 and the seasonal mean (average of all stations in each season) were tested by ANOVA method, and by Fisher's PLSD for multiple comparisons if ANOVA was significant. Multiple regression was used for evaluating the relationships between the abundance of the five most dominant phytoplankton species and the hydrological variables.

\section{RESULTS}

\section{Hydrography and copepods}

Seasonal changes in hydrographic factors and copepod abundance in the waters of both NPPs and seasonal mean (average of all stations in each season) are shown in Figure 2. Sea surface temperature of NPP1 and NPP2 showed significant seasonal changes (ANOVA, $p<$ 0.05 ), usually increased up to $28^{\circ} \mathrm{C}$ in August and dropped to about $20^{\circ} \mathrm{C}$ in $\mathrm{March}$ in seasonal average. The sea surface temperature was not significant between NPP1, NPP2 and seasonal mean. The trend of seasonal changes in salinity was opposite to temperature, highest in March and the lowest in August, and varied between 33.0 psu and 34.5 psu. No significant differ-

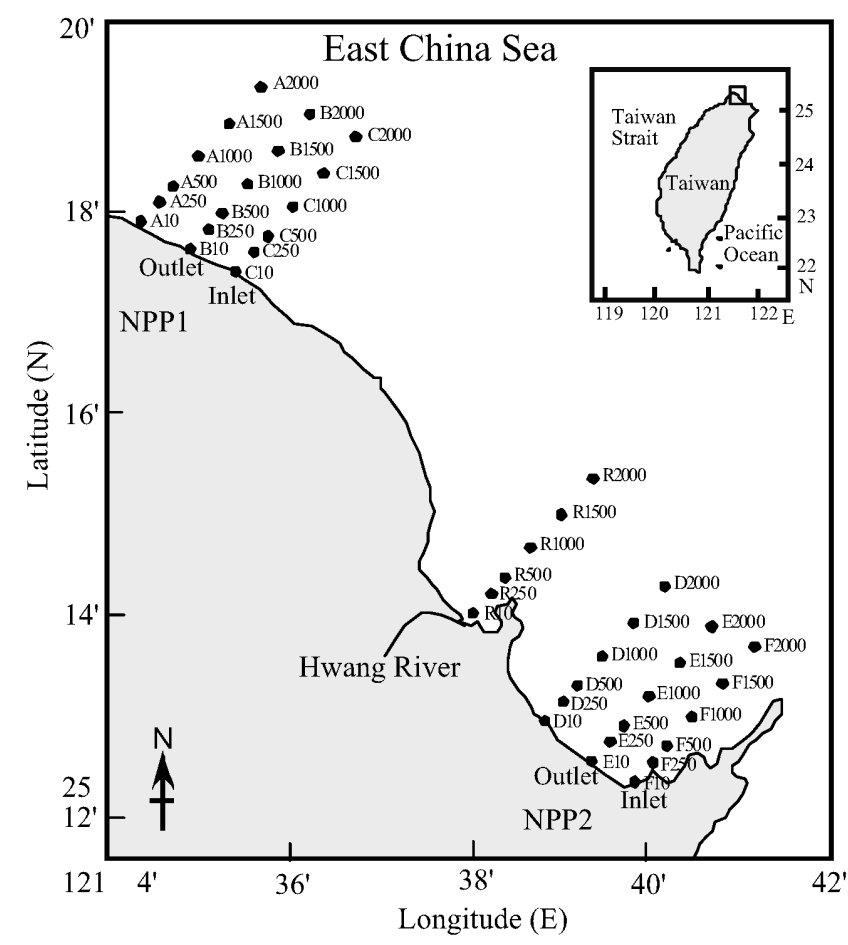

Fig 1. Location of sampling stations in the waters off NPP1 and NPP2 of northern Taiwan. The letter and number of each station represent transect and distance $(\mathrm{m})$ from land. 
ences in salinity were found between the seasonal mean and both NPPs. The concentrations of phosphate and silicate showed no significant difference between stations and seasons, while the concentration of nitrate exhibited significant seasonal change, highest in March and lowest in August (Fisher's PLSD, $p<0.05$ ). The copepod abundance showed larger variations among seasons and stations (ANOVA, $p<0.05$ ), higher in the waters of NPP2 in August and lower in the waters of NPP1 in October.

\section{Species diversity}

Among the total of 265 phytoplankton taxa identified, more species were found in 2002 (256 spp.)
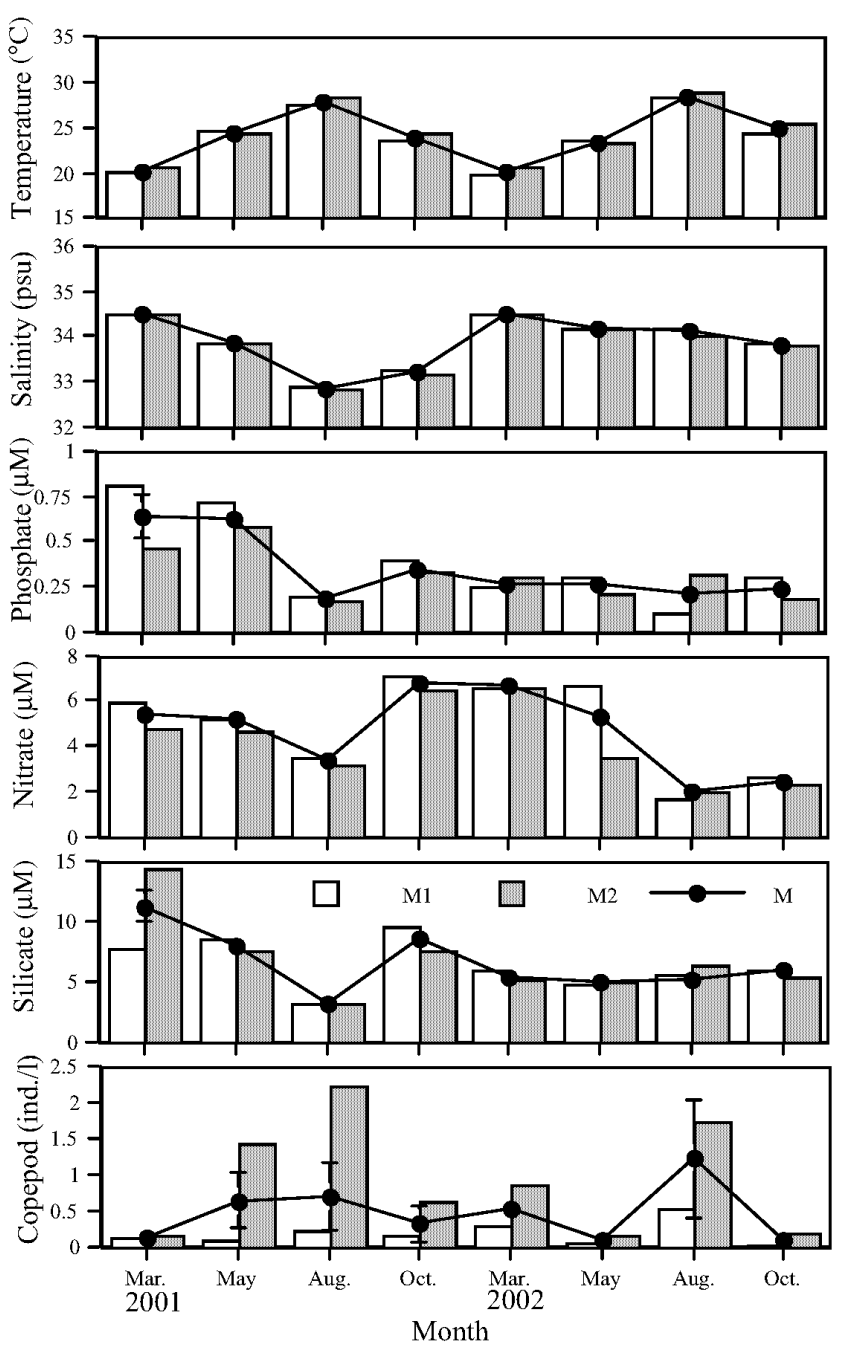

Fig. 2. Seasonal distribution of temperature, salinity, phosphate, nitrate, silicate and copepod in the waters of NPP1 and NPP2 of northern Taiwan during 2001-02. $M=$ the average $( \pm S E)$ of all stations in each season; $M 1=$ the average of all stations of NPP1 in each season; M2 = the average of all stations of NPP2 in each season. than in 2001 (159 spp.) (Table 1). The highest species number was recorded in May 2002 (164 spp.) and the lowest in March 2001 (91 spp.). In the waters of NPP1 usually had higher species number and diversity than that of NPP2, particularly in August 2002 that NPP1 has the lowest values of species number and diversity index. Chaetoceros compressus, Pseudo-nitzschia delicatissima, Skeletonema costatum, Thalassionema nitzschioides, and Lauderia annulata were the five dominant species and comprised $75 \%$ of the total phytoplankton cells. P. delicatissima and T. nitzschioides ranked first and second in abundance in 2001, while C. compressus and $S$. costatum dominated in 2002, particularly in summer that both species bloomed and contained $80 \%$ of the total cells (Table 2).

\section{Seasonal and spatial distribution}

The phytoplankton abundance showed clear annual and seasonal changes, higher in 2002 and in summer (August) within the year (Table 1). The spatial distribution pattern in abundance of phytoplankton varied seasonally, usually higher in inshore waters, particularly at NPP2 and Hwang River in March and August 2002 (Figure 3). In the waters of NPP1 usually had higher phytoplankton abundance than that of NPP2 and the seasonal and annual mean in 2001, but higher phytoplankton abundance was generally found in the waters of NPP2 in 2002. The highest phytoplankton abundance was found in the waters of NPP2 in August 2002 and the lowest in the waters of NPP1 in March 2001 (Table 1). Among the 5 dominant species, Cheatoceros compressus

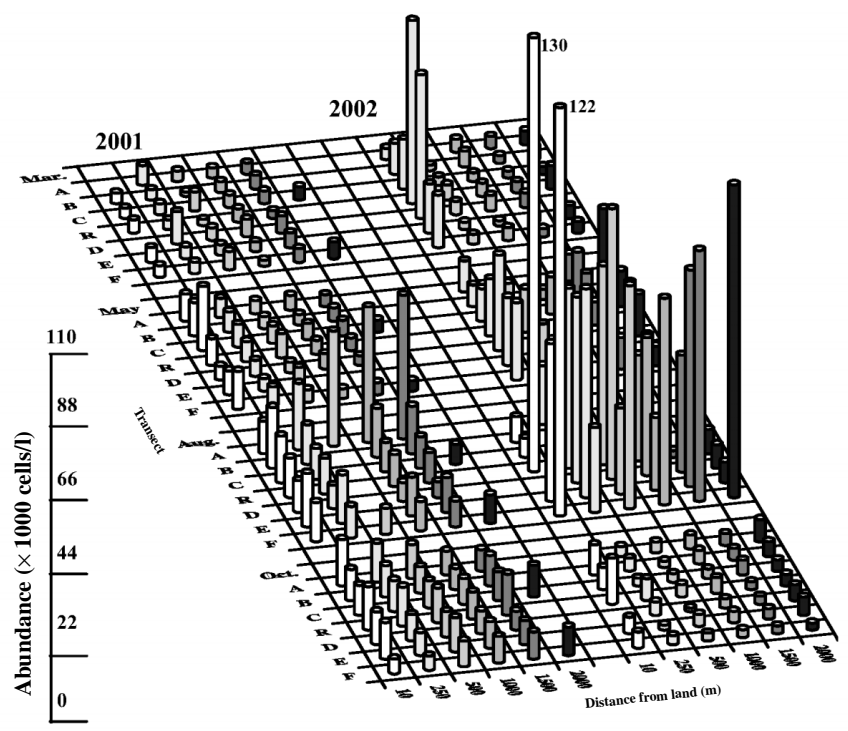

Fig. 3. The distribution of phytoplankton in the waters off NPP1 (transects A, B, C) and NPP2 (transects D, E, F) and Hwang River (transect $R$ ) of northern Taiwan during 2001-02. 
Table 1. The abundance $\left(\times 10^{3}\right.$ cells/L), species number and diversity index of phytoplankton in the waters off NPP1 and NPP2 of northern Taiwan during 2001-02. $M=$ the average $( \pm S E)$ of all stations; $T=$ Total; $M 1=$ the average $( \pm S E)$ of all stations of NPP1; M2 $=$ the average $( \pm$ SE) of all stations of NPP2

\begin{tabular}{|c|c|c|c|c|c|}
\hline Year/month & Mar. 2001 & May 2001 & Aug. 2001 & Oct. 2001 & Annual mean (or total) \\
\hline $\begin{array}{l}\text { No of } \\
\text { Abun }\end{array}$ & $\begin{array}{l}35 \\
\text { M: } 3.71 \pm 0.24 \\
\text { M1: } 3.62 \pm 0.28 \\
\text { M 2: } 4.41 \pm 0.46\end{array}$ & $\begin{array}{l}37 \\
\text { M: } 5.60 \pm 0.60 \\
\text { M1: } 6.09 \pm 0.99 \\
\text { M2: } 4.72 \pm 0.53\end{array}$ & $\begin{array}{l}32 \\
\text { M: } 12.74 \pm 1.52 \\
\text { M1: } 18.16 \pm 3.25 \\
\text { M2: } 9.56 \pm 0.84\end{array}$ & $\begin{array}{l}37 \\
\text { M: } 7.96 \pm 0.36 \\
\text { M1: } 8.97 \pm 0.47 \\
\text { M2: } 7.68 \pm 0.46\end{array}$ & $\begin{array}{l}\text { M: } 6.80 \pm 0.46 \\
\text { M1: } 9.01 \pm 1.04 \\
\text { M2: } 6.53 \pm 0.39\end{array}$ \\
\hline Species number & $\begin{array}{l}\text { T: } 91 \\
\text { M: } 28 \pm 1 \\
\text { M1: } 30 \pm 2 \\
\text { M2: } 29 \pm 1\end{array}$ & $\begin{array}{l}\text { T: } 105 \\
\text { M: } 37 \pm 1 \\
\text { M1: } 36 \pm 2 \\
\text { M2: } 36 \pm 2\end{array}$ & $\begin{array}{l}\text { T: } 97 \\
\text { M: } 47 \pm 2 \\
\text { M1: } 52 \pm 3 \\
\text { M2: } 44 \pm 3\end{array}$ & $\begin{array}{l}\text { T: } 107 \\
\text { M: } 40 \pm 1 \\
\text { M1: } 41 \pm 2 \\
\text { M2: } 40 \pm 1\end{array}$ & $\begin{array}{l}\text { T: } 159 \\
\text { M: } 38 \pm 1 \\
\text { T1: } 71 ; \text { M } 1: 39 \pm 2 \\
\text { T2: } 75 ; \text { M } 2: 37 \pm 1\end{array}$ \\
\hline $\begin{array}{l}\text { Species diversity } \\
\text { index }\end{array}$ & $\begin{array}{l}\text { M: } 4.02 \pm 0.06 \\
\text { M1: } 4.18 \pm 0.10 \\
\text { M2: } 3.98 \pm 0.07\end{array}$ & $\begin{array}{l}\text { M: } 4.17 \pm 0.09 \\
\text { M1: } 4.31 \pm 0.08 \\
\text { M2: } 3.94 \pm 0.16\end{array}$ & $\begin{array}{l}\text { M: } 4.19 \pm 0.06 \\
\text { M1: } 4.12 \pm 0.10 \\
\text { M2: } 4.21 \pm 0.11\end{array}$ & $\begin{array}{l}\text { M: } 4.11 \pm 0.04 \\
\text { M1: } 4.10 \pm 0.06 \\
\text { M2: } 4.17 \pm 0.05\end{array}$ & $\begin{array}{l}\text { M: } 4.12 \pm 0.03 \\
\text { M1: } 4.18 \pm 0.04 \\
\text { M2: } 4.07 \pm 0.05\end{array}$ \\
\hline Year/month & Mar. 2002 & May 2002 & Aug. 2002 & Oct. 2002 & Annual mean (or total) \\
\hline $\begin{array}{l}\text { No of sample } \\
\text { Abundance }\end{array}$ & $\begin{array}{l}35 \\
\text { M: } 6.50 \pm 3.33 \\
\text { M1: } 4.37 \pm 0.88 \\
\text { M2: } 7.54 \pm 2.77\end{array}$ & $\begin{array}{l}34 \\
\text { M: } 11.08 \pm 0.94 \\
\text { M1: } 10.29 \pm 1.21 \\
\text { M2: } 12.25 \pm 1.92\end{array}$ & $\begin{array}{l}40 \\
\text { M: } 27.73 \pm 5.14 \\
\text { M1: } 5.37 \pm 0.90 \\
\text { M2: } 52.54 \pm 7.54\end{array}$ & $\begin{array}{l}40 \\
\text { M: } 4.06 \pm 0.34 \\
\text { M1: } 4.13 \pm 0.44 \\
\text { M2: } 3.20 \pm 0.31\end{array}$ & $\begin{array}{l}\text { T: } 149 \\
\text { M: } 12.34 \pm 1.23 \\
\text { M1: } 5.89 \pm 0.52 \\
\text { M2: } 19.44 \pm 3.30\end{array}$ \\
\hline Specie & $\begin{array}{l}\text { T: } 138 \\
\text { M: } 21 \pm 1 \\
\text { M1: } 20 \pm 1 \\
\text { M2: } 22 \pm 1\end{array}$ & $\begin{array}{l}\text { T: } 164 \\
\text { M: } 27 \pm 1 \\
\text { M1: } 28 \pm 1 \\
\text { M2: } 30 \pm 3\end{array}$ & $\begin{array}{l}\text { T: } 104 \\
\text { M: } 18 \pm 1 \\
\text { M1: } 20 \pm 1 \\
\text { M2: } 18 \pm 1\end{array}$ & $\begin{array}{l}\text { T: } 121 \\
\text { M: } 20 \pm 1 \\
\text { M1: } 21 \pm 1 \\
\text { M2: } 19 \pm 1\end{array}$ & $\begin{array}{l}\text { T: } 256 \\
\text { M: } 22 \pm 1 \\
\text { T1: } 87 ; \text { M1: } 22 \pm 1 \\
\text { T2: } 96 ; \text { M2: } 22 \pm 1\end{array}$ \\
\hline $\begin{array}{l}\text { Species diversity } \\
\text { index }\end{array}$ & $\begin{array}{l}\text { M: } 3.32 \pm 0.10 \\
\text { M1: } 3.23 \pm 0.17 \\
\text { M2: } 3.37 \pm 0.16\end{array}$ & $\begin{array}{l}\text { M: } 3.57 \pm 0.05 \\
\text { M1: } 3.70 \pm 0.06 \\
\text { M2: } 3.58 \pm 0.08\end{array}$ & $\begin{array}{l}\text { M: } 2.34 \pm 0.18 \\
\text { M1: } 3.45 \pm 0.09 \\
\text { M2: } 1.35 \pm 0.18\end{array}$ & $\begin{array}{l}\text { M: } 3.51 \pm 0.07 \\
\text { M1: } 3.62 \pm 0.09 \\
\text { M2: } 3.47 \pm 0.09\end{array}$ & $\begin{array}{l}\text { M: } 3.19 \pm 0.05 \\
\text { M1: } 3.50 \pm 0.06 \\
\text { M2: } 2.91 \pm 0.14\end{array}$ \\
\hline
\end{tabular}

Table 2. The mean abundance $( \pm \mathrm{SE})$ and relative abundance of the five most dominant phytoplankton species in the waters off NPP 1 and NPP2 of northern Taiwan, during 2001-02

\begin{tabular}{|c|c|c|c|c|}
\hline Mar. 2001 & May 2001 & Aug. 2001 & Oct. 2001 & 2001 overall mean \\
\hline $\begin{array}{l}\text { Thalassionema nitzschioides } \\
(19.0 \%, 705 \pm 51 \text { cells/L) }\end{array}$ & $\begin{array}{l}\text { Chaetoceros compressus } \\
(16.3 \%, 911 \pm 356 \text { cells } / \mathrm{L})\end{array}$ & $\begin{array}{l}\text { Lauderia annulata } \\
(14.83 \%, 1,890 \pm 262 \text { cells/L) }\end{array}$ & $\begin{array}{l}\text { Pseudo-nitzschia delicatissima } \\
(16.18 \%, 1,288 \pm 107 \text { cells/L) }\end{array}$ & $\begin{array}{l}\text { Pseudo-nitzschia delicatissima } \\
(12.92 \%, 879 \pm 58 \text { cells/L) }\end{array}$ \\
\hline $\begin{array}{l}\text { Pseudo-nitzschia delicatissima } \\
(15.3 \%, 567 \pm 56 \text { cells/L) }\end{array}$ & $\begin{array}{l}\text { Thalassionema nitzschioides } \\
(13.5 \%, 758 \pm 80 \text { cells/L) }\end{array}$ & $\begin{array}{l}\text { Leptocylindrus danicus } \\
(13.40 \%, 1,709 \pm 343 \text { cells/L) }\end{array}$ & $\begin{array}{l}\text { Skeletonema costatum } \\
(14.06 \%, 1,120 \pm 83 \text { cells/L) }\end{array}$ & $\begin{array}{l}\text { Thalassionema nitzschioides } \\
(11.14 \%, 758 \pm 35 \text { cells/L) }\end{array}$ \\
\hline $\begin{array}{l}\text { Chaetoceros compressus } \\
(8.0 \%, 296 \pm 52 \text { cells/L) }\end{array}$ & $\begin{array}{l}\text { Pseudo-nitzschia delicatissima } \\
(9.7 \%, 544 \pm 45 \text { cells/L) }\end{array}$ & $\begin{array}{l}\text { Cylindrotheca closterium } \\
(8.75 \%, 1,116 \pm 117 \text { cells/L) }\end{array}$ & $\begin{array}{l}\text { Leptocylindrus danicus } \\
(9.75 \%, 776 \pm 55 \text { cells/L) }\end{array}$ & $\begin{array}{l}\text { Leptocylindrus danicus } \\
(9.98 \%, 678 \pm 89 \text { cells/L) }\end{array}$ \\
\hline $\begin{array}{l}\text { Cylindrotheca closterium } \\
(6.3 \%, 232 \pm 21 \text { cells/L) }\end{array}$ & $\begin{array}{l}\text { Leptocylindrus danicus } \\
(5.0 \%, 282 \pm 65 \text { cells/L) }\end{array}$ & $\begin{array}{l}\text { Pseudo-nitzschia delicatissima } \\
(8.44 \%, 1,076 \pm 172 \text { cells/l })\end{array}$ & $\begin{array}{l}\text { Thalassionema nitzschioides } \\
(9.08 \%, 723 \pm 70 \text { cells/L) }\end{array}$ & $\begin{array}{l}\text { Chaetoceros compressus } \\
(8.92 \%, 606 \pm 97 \text { cells/L) }\end{array}$ \\
\hline $\begin{array}{l}\text { Leptocylindrus danicus } \\
(4.2 \%, 155 \pm 23 \text { cells/L) }\end{array}$ & $\begin{array}{l}\text { Cylindrotheca closterium } \\
(4.4 \%, 248 \pm 24 \text { cells/L) }\end{array}$ & $\begin{array}{l}\text { Chaetoceros curvisetus } \\
(7.41 \%, 945 \pm 106 \text { cells/L) }\end{array}$ & $\begin{array}{l}\text { Chaetoceros compressus } \\
(6.54 \%, 521 \pm 52 \text { cells/L) }\end{array}$ & $\begin{array}{l}\text { Lauderia annulata } \\
(7.02 \%, 478 \pm 82 \text { cells/L) }\end{array}$ \\
\hline Mar. 2002 & May 2002 & Aug. 2002 & Oct. 2002 & 2002 overall mean \\
\hline $\begin{array}{l}\text { Lauderia annulata } \\
(27.0 \%, 1,756 \pm 765 \text { cells/L) }\end{array}$ & $\begin{array}{l}\text { Pseudo-nitzschia delicatissima } \\
(19.2 \%, 2,131 \pm 190 \text { cells/L) }\end{array}$ & $\begin{array}{l}\text { Chaetoceros compressus } \\
(60.7 \%, 16,832 \pm 3800 \text { cells/L) }\end{array}$ & $\begin{array}{l}\text { Pseudo-nitzschia delicatissima } \\
(21.2 \%, 860 \pm 105 \text { cells/L) }\end{array}$ & $\begin{array}{l}\text { Chaetoceros compressus } \\
(54.5 \%, 4,699 \pm 664 \text { cells/L) }\end{array}$ \\
\hline Chaetoceros compressus & Thalassionema nitzschioides & Skeletonema costatum & Lauderia annulata & Skeletonema costatum \\
\hline$(8.8 \%, 570 \pm 532$ cells $/ \mathrm{L})$ & $(12.3 \%, 1,366 \pm 268$ cells/L) & $(19.2 \%, 5,334 \pm 2585$ cells $/ \mathrm{L})$ & $(5.7 \%, 232 \pm 28$ cell & $(15.3 \%, 1,354 \pm 217 \mathrm{cel}$ \\
\hline $\begin{array}{l}\text { Thalassionema nitzschioides } \\
(6.8 \%, 440 \pm 76 \text { cells } / \mathrm{L})\end{array}$ & $\begin{array}{l}\text { Chaetoceros compressus } \\
(11.0 \%, 1,223 \pm 325 \text { cells/L) }\end{array}$ & $\begin{array}{l}\text { Chaetoceros curvisetus } \\
(4.0 \%, 1,106 \pm 552 \text { cells/L) }\end{array}$ & $\begin{array}{l}\text { Cylindrotheca closterium } \\
(5.7 \%, 231 \pm 29 \text { cells/L) }\end{array}$ & $\begin{array}{l}\text { Pseudo-nitzschia delicatissima } \\
(11.9 \%, 1076 \pm 64 \text { cells/L) }\end{array}$ \\
\hline Melosira sulcata & Cylindrotheca closterium & Pseudo-nitzschia delicatissima & Grammatophora hamulifera & Lauderia annulata \\
\hline & & $(3.9 \%, 1,072 \pm 122$ cells $/ \mathrm{L})$ & & \\
\hline $\begin{array}{l}\text { Chaetoceros curvisetus } \\
(4.8 \%, 314 \pm 250 \text { cells/L) }\end{array}$ & $\begin{array}{l}\text { Chaetoceros curvisetus } \\
(6.5 \%, 719 \pm 143 \text { cells/L) }\end{array}$ & $\begin{array}{l}\text { Cylindrotheca closterium } \\
(1.4 \%, 380 \pm 53 \text { cells/L) }\end{array}$ & $\begin{array}{l}\text { Chaetoceros curvisetus } \\
(4.4 \%, 180 \pm 44 \text { cells/L) }\end{array}$ & $\begin{array}{l}\text { Chaetoceros curvisetus } \\
(6.8 \%, 563 \pm 36 \text { cells } / \mathrm{L})\end{array}$ \\
\hline
\end{tabular}


Table 3. Multiple regression coefficients of the 5 dominant phytoplankton species in the waters off NPP1 and NPP2 of northern Taiwan during 2001-02

\begin{tabular}{lcccccc}
\hline & Temp. & Sal. & PO4 & NO3 & Si & Copepoda \\
\hline Chaetoceros compressus & $34.165^{* * *}$ & 0.197 & -0.238 & $-17.450^{* * *}$ & -1.158 & 0.016 \\
Pseudo-nitzschia delicatissima & $10.214^{* *}$ & $-7.177^{* *}$ & -1.103 & -2.744 & $-4.476^{*}$ & 3.218 \\
Skeletonema costatum & $14.748^{* * *}$ & -1.747 & 0.030 & -2.686 & -0.634 & 0.001 \\
Thalassionema nitzschioides & $-6.840^{*}$ & -3.839 & $4.674 *$ & $37.136^{* * *}$ & 1.611 & -1.000 \\
Lauderia annulata & $22.427^{* * *}$ & $-63.309^{* * *}$ & -3.268 & -2.431 & $-14.373^{* * *}$ & -0.343 \\
Total phytoplankton & $49.632^{* * *}$ & -2.857 & -0.319 & $-14.254^{* * *}$ & $-4.217 *$ & 0.018 \\
Species no. & 1.780 & $-111.605^{* * *}$ & $4.202^{*}$ & $9.043 * *$ & 0.477 & -0.326 \\
Species diversity index & $-27.525^{* * *}$ & $-10.855^{* *}$ & $9.386^{* *}$ & $31.094 * * *$ & 3.339 & -0.564 \\
\hline
\end{tabular}

Species as dependent variables are listed in rows, and environmental factors as independent variables are listed in columns. *Significant at the 0.05 level; **significant at the 0.01 level; ***significant at the 0.001 level.

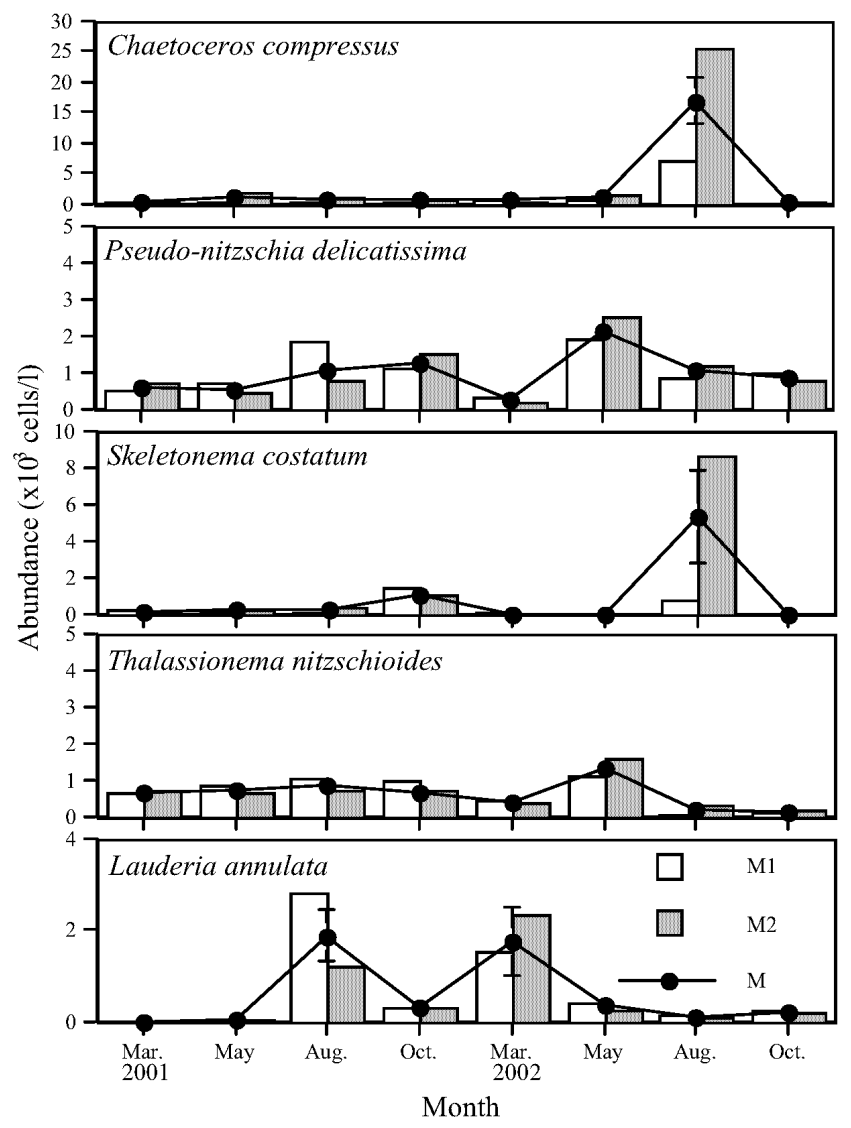

Fig 4. Seasonal distribution in abundance of the five dominant phytoplankton species in the waters of NPP1 and NPP2 of northern Taiwan during 2001-02. $M=$ average abunance $( \pm S E)$ of all stations in each season; $M 1=$ the average of all stations of NPP1 in each season; M2 = the average of all stations of NPP2 in each season.

and Skeletonema costatum had higher abundance in the waters of NPP2 than that of NPP2 and showed a peak abundance in the waters of NPP2 in August 2002 (Figure 4). Pseudo-nitzschia delicatissima and, Thalassionema nitzschioides showed a similar trend of seasonal abundance, higher in August or May and lower in March, but varied from year to year, with no significant difference between NPP1 and NPP2. Lauderia annulata showed higher abundance in August 2001 and March 2002 , with insignificant difference in abundance between NPPs and the seasonal mean abundance (ANOVA, $p>0.05)$.

\section{Phytoplankton and environmental variables}

The abundance of total phytoplankton was positively correlated with temperature $(p<0.001)$ and negatively with nitrate $(p<0.001)$ and silicate $(p<0.05)$, but insignificantly with salinity, phosphate, and copepods (Table 3). The species number of phytoplankton was negatively correlated with salinity $(p<0.001)$ and positively with nitrate $(p<0.01)$ and phosphate $(p<$ $0.05)$, but insignificantly with temperature, silicate and copepods. The index of species diversity of phytoplankton was negatively correlated with temperature ( $p<$ $0.001)$ and salinity $(p<0.01)$ and positively with nitrate $(p<0.001)$ and phosphate $(p<0.01)$, but not significantly with silicate or copepods. Among the 5 dominant phytoplankton taxa, Chaetoceros compressus, Pseudonitzschia delicatissima, Skeletonema costatum, and Lauderia annulata showed significant positive correlations with temperature $(p<0.01)$ but Thalassionema nitzschioides was negative correlated $(p<0.05)$. Many dominant species exhibited negative correlations with salinity, but only $L$. borealis and $P$. delicatissima were significantly correlated $(p<0.01)$. Different dominant species displayed different correlations with nutrients, for instance, $C$. compressus had a significant negative correlation with nitrate $(p<0.001), P$. delicatissima and $L$. borealis had a significant negative correlation with silicate $(p<0.05)$, whereas $T$. nitzschioides exhibited significant positive correlations with nitrate $(p<0.001)$ and phosphate $(p<0.05)$. All dominant species showed 
no significant correlations with copepods.

\section{DISCUSSION}

The species composition and abundance of phytoplankton revealed distinct spatial and temporal patterns in the waters off NPP1 and NPP2, north of Taiwan. Higher phytoplankton abundance was usually found in summer (August) and in inshore waters (Table 1, Figure 3 ). The annual mean abundance of 2002 was about 2 times higher than that of 2001, but it was obviously lower when compared with the previous results in the same study areas (Hung et al., 1997, 1998; Lo et al., 1999). This is because mass abundance of some dominant species occasionally occurred in inshore waters during warmer seasons (from May to October) in previous studies. For instance, Thalassionema nitzschioides bloomed in the inshore waters of NPP2 in October 1998 and the mass abundance of Chaetoceros curvisetus was found in the estuary of Hwang River in July 1999 (Lo et al., 1999). However, these species were not predominant though common in the phytoplankton community during the present study period. The abundance of phytoplankton in this study was similar to or less than the previous study in the waters around Penghu Islands (Lo, 1998a) and much lower than that in the coastal waters of southwestern Taiwan (Lo, 1998b; Mok and Lo, 1999). The waters around Penghu Islands are mostly coral reef $s$ and usually form the island mass effect, which is a disturbance in the flow of water (e.g. the northward Kuroshio Current and South China Sea Water) caused by the presence of an island; resulting in upwelling and subsequent nutrient and primary production enrichments of surface water (Shaw, 1989; Lo et al., 2004). While the coastal waters of southwestern Taiwan are usually eutrophic due to the heavy industry and urban pollutions from Kaohsiung Harbor and Kaoping River; for instance, Skeletonema costatum usually bloomed in spring and summer, and, once up to $1.5 \times 10^{6}$ cells/L during a case of oil pollution in the coastal waters off Kaohsiung Harbor in 1997 (Lo, 1998b). The adjacent waters off NPP1 and NPP2, when compared with the above areas, showed lower phytoplankton abundance, probably due to the lesser degree of industry pollution and urban drainage and usually the impact of the nutrient-poor Kuroshio Branch Current (Chen, 2000).

The phytoplankton community showed clear seasonal succession in this study area although the community structure was similar between 2001 and 2002. For instance, the most dominant species, Chaetoceros compressus, is a typical warm water and neritic species characterized by a pair of setae between cells and usually forms a long chain colony in well environmental conditions. This species comprised $54 \%$ of the total cells in this study and performed a clear seasonal succession, increasing in abundance with increasing water temperature (Table 3). It usually bloomed in inshore waters during summer season, especially in August 2002 (Table 2, Figure 4). Pseudo-nitzschia delicatissima, a very common species in this area, showed no distinct seasonal change in abundance. It usually became the most dominant species in cooler seasons (e.g., October) or when the abundance of $C$. compressus or the total phytoplankton was low. Skeletonema costatum is a very common centric diatom in worldwide neritic waters and lagoon (Badylak and Phlip, 2004) and well known for its euryhaline character (Rijstenbil, 1988). It was a dominant diatom in the southwest waters of Taiwan and usually was regarded as an indicator species of pollution and eutrophication (Lo, 1998b). It was also common in this study and increased significantly with temperature in abundance and usually bloomed in warmer inshore waters. Thalassionema nitzschioides, a cosmopolitan neritic and oceanic diatom (Marshall, 1982), was a common species in this area and usually ranked number 1 to 3 in abundance in March or May (Table 2). It was the only species having negative correlation with temperature ( $p$ $<0.05$ ) among the top 5 dominant phytoplankton species (Table 3). Lauderia annulata was the most dominant species in August 2001 and March 2002. Its abundance increased with increasing temperature and apparently influenced by salinity and silicate. The five dominant diatom species in the present study were also very common in the East China Sea and each was correlated with different water mass (Chiang et al., 1999). P. delicatissima was very common in all stations, Chaetoceros compressus dominated in upwelling and shelf-break waters, and T. nitzschioides was the major taxon in background assemblage. Furthermore, Chaetoceros curvisetus, a dominant species of coastal assemblage suggested by Chiang et al. (1999), was also common in the coastal waters of the NPPs and ranked 6 th in abundance of the total cells.

Our results suggest that the phytoplankton community should be not influenced by the thermal discharge of NPPs in the adjacent waters. Higher phytoplankton abundance and species number were frequently observed in the inshore waters of both NPPs if compared with the offshore waters (Figure 3). No significant differences in abundance and species number were found between the outlet and other inshore stations (ANOVA, $p<0.05$ ). These findings implied that higher abundance was common and frequent phenomena in inshore waters and the scale of seasonal change in temperature was more significant than that of the thermal discharge of NPPs. Moreover, the topo- 
graphic condition might be an indispensable factor to be considered in this study. NPP2 is located within a semienclosed bay, while NPP1 is facing open ocean. The water interchange rate between inshore and offshore areas was thus slower in NPP2 than in NPP1 and the difference may influence the dispersion efficiency of the thermal discharge, particularly in calm summer season in inshore waters of NPP2 where phytoplankton bloom usually occurred (e.g, August 2002). The impact of the thermal discharge from power plant on phytoplankton has been previous reported by many studies. Lin et al. (2001) studied the phytoplankton biomass and productivity in the NPP2 and found no significant difference between the outlet and inlet stations. They suggested that the thermal discharge of the NPP2 should not affect the phytoplankton biomass and productivity, but might influence the species composition and biomass of periphyton at the outlet area, particularly in summer season. Similar result was also reported by Lee (2000) for bacteria in NPP2, by Hirayama and Hirano (1970) for two marine phytoplankton (Chlamydomonas sp. and Skeletonema costatum) in laboratory. Mercado and Gomez (1999) studied in the Lower Parana River and proposed that, with well prevention procedure and proper equipment, the effects of the thermal discharge from a nuclear power plant on phytoplankton abundance, productivity, and diversity are generally insignificant.

In conclusion, the phytoplankton community is diverse in this study area, probably due to the complexities of hydrographic conditions. The offshore waters of NPPs usually formed a small scale of upwelling due to the interaction of tidal current, the East China Sea shelf water, and the Kuroshio Branch Current (Hu, 2000), and thus making higher abundance and species richness occur occasionally at some offshore stations. Although we had no enough temperature data at the outlet stations of the NPPs, our results showed that the impact of thermal discharge from the NPPs on the marine phytoplankton community should be minimal and occasionally beneficial, probably due to fast reproductive and recovery time of the latter. The variation of phytoplankton assemblages is more obvious in seasonal scale than in spatial scale within the same season. Our results indicated that multiple environmental variables, such as river runoff, local hydrography and weather condition might also play the forcing functions to influence the phytoplankton community in this area.

\section{ACKNOWLEDGEMENTS}

This research was supported by a grant from the Taiwan Power Company to W. T. Lo. We are grateful for the assistance in the field from the skipper, crew, and technicians of the RV "Ocean Researcher II". We also acknowledge Prof. C.T. Shih for his advice and comments on the manuscript.

\section{REFERENCES}

1. Badylak, S. and Phlip, E.J., "Spatial and Temporal Patterns of Phytoplankton Composition in a Subtropical Coastal Lagoon, the Indian River Lagoon, Florida, USA," J. Plankton Res., Vol. 26, No. 10, pp. 1229-1247 (2004).

2. Chen, Y.L., Comparisons of Primary Productivity and Phytoplankton Size Structure in the Marginal Regions of Southern East China Sea," Cont. Shelf Res., Vol. 20, pp. 437-458 (2000).

3. Chiang, K.P., Chen, Y.T., and Gong, G.C., "Spring Distribution of Diatom Assemblages in the East China Sea," Mar. Ecol. Prog. Ser., Vol. 186, pp. 75-86 (1999).

4. Chihara, M. and Murano, M., An Illustrated Guide to Marine Plankton in Japan. Tokai University Press, Tokyo, pp. 3-330 (1997).

5. Cottingham, K.L., "Nutrients and Zooplankton as Multiple Stressors of Phytoplankton Communities: Evidence from Size Structure," Limnol. Oceanogr., Vol. 44, pp. 810-827 (1999).

6. Hirayama, K. and Hirano, R., "Influences of High Temperature and Residual Chlorine on Marine Phytoplankton," Mar. Biol., Vol. 7, pp. 205-213 (1970).

7. Hu, J.H., The Ecological Investigation in the Adjacent Waters of Nuclear Power Plants, North of Taiwan, During 1996-1997. -Ocean and Tidal Currents. Technique Report of Taiwan Power Company, Taipei, Taiwan, pp. 1-90 (2000). (in Chinese, with English abstract)

8. Hung, T.C., Hwang, S., Tan, T.H., Shao, K. T., Huang, C.C., Chen, N.C., Chu, T.C., and Fan, K.L., "The Ecological Investigation in the Adjacent Waters of Nuclear Power Plants, North of Taiwan, During 1996-1997," Special Issue of Academia Sinica, Committee of International Environmental Science. Vol. 101, pp. 1-297 (1997). (in Chinese)

9. Hung, T.C., Hwang, S., Tan, T.H., Shao, K.T., Huang, C.C., Chen, N.C., Chu, T.C., and Fan, K.L., "The Ecological Investigation in the Adjacent Waters of Nuclear Power Plants, North of Taiwan, During 1996-1998," Special Issue of Academia Sinica, Committee of International Environmental Science. Vol. 102, pp. 1-549(1998). (in Chinese)

10. Ikäheimonen, T.K., Klemola, S., Ilus, E., and Sjoblom, K.L., Monitoring of Radionuclides in the Vicinities of Finnish Nuclear Power Plants in 1991-1992. Report STUK-A-121, Finnish Centre for Radiation and Nuclear Safety, Helsinki, pp. 1-96 (1995).

11. Ilus, E., Sjöblom, K.L., Aaltonen, H., Klemola, S., and Arvela, H., Monitoring of Radioactivity in the Environs of Finnish Nuclear Power Stations in 1986. Report 
STUK-A67, Finnish Centre for Radiation and Nuclear Safety, Helsinki. pp. 1-82 (1987).

12. Ilus, E., Sjöblom, K.L., Klemola, S., and Arvela, H., Monitoring of Radionuclides in the Environs of Finnish Nuclear Power Plants in 1989-1990. Report STUK-A102, Finnish Centre for Radiation and Nuclear Safety, Helsinki, pp. 1-91. (1992).

13. Ingrid, G., Andersen, T., and Vadstein, O., "Pelagic Food Webs and Eutrophication of Coastal Waters: Impact of Grazers on Algal Communities," Mar. Pollut. Bull., Vol. 33, pp. 22-35 (1996).

14. Keskitalo, J. and Ilus, E., “Aquatic Macrophytes Outside the Olkiluoto Nuclear Power Station, West Coast of Finland," Ann. Bot. Fennici, Vol. 24, pp. 1-21 (1987).

15. Lee, S.I., "The Abundance of Autotrophic Bacteria in the Thermal Discharge of Power Plants," Report of National Science Council, Taipei, Taiwan, pp. 10611065 (2000). (in Chinese)

16. Lin, H.J., Yang, H.H., Tu, Y.Y., and Tsai, H.S., "Productivity and Abundance of Phytoplankton and Periphyton at the Second Nuclear Power Plant," Monthly Issue Taiwan Power Co., Vol. 650, No. 10, pp. 82-90 (2002). (in Chinese, with English Abstract)

17. Lo, W.T., The Investigation and Assessment on the Fish-Farming Cage in the Waters around Penghu Islands. -Plankton and Fishery Resources, Technique Report of Penghu County Government, Penghu, Taiwan, pp. 242-249 (1998a). (in Chinese)

18. Lo, W.T., The Investigation of Oil Pollution on Water Quality and Ecological Communities in the Waters off Kaohsiung Harbor. - Zooplankton and Phytoplankton. Technique Report of China Oil Company, Taipei, Taiwan, pp. 342-353 (1998b). (in Chinese)

19. Lo, W.T., Hwang, J.S., and Chen, Q.C., "Spatial Distributions of Copepods in Surface Waters of the Southeastern Taiwan Strait," Zool. Stud., Vol. 43, No. 2, 218-228 (2004).

20. Lo, W.T., Hwang, J.J., and Wu, W.G., The Ecological Investigation in the Adjacent Waters of Nuclear Power Plants, North of Taiwan. -I. Phytoplankton. Technique Report of Taiwan Power Company, Taipei, Taiwan, Ch. 3, pp. 1-60 (1999).
21. Marshall, H.G., "The Composition of Phytoplankton within the Chesapeake Bay Plume and Adjacent Waters off the Virginia Coast," Estaur. Coast. Shelf Sci., Vol. 15, pp 29-43 (1982).

22. Mercado, L.M. and Gomez, N., "Effects of a Nuclear Power Plant on Phytoplankton Structure of the Lower Parana River," Interciencia, Vol. 24, No. 1, pp. 36-41 (1999).

23. Mok, H.K. and Lo, W.T., The Investigation of the Effect of Marine Sand and Gravel Extraction on the Fishery Resources, Macrobenthos and Plankton Communities in the Neritic Waters of Tainan. Technique Report of Industrial Technology Research Institute, Energy and Resources Laboratories, Hsinchu, Taiwan (1999). (in Chinese)

24. Nagy, G., Tilky, P., Horvath, A., Pinter, T., and Schiller, R. "Kinetic and Statical Analysis of Primary Circuit Water Chemistry Data in a VVER Power Plant," Nuclear Technol., Vol. 136, No. 3, pp. 331-341 (2001).

25. Ovari, M., Csukas, M., and Zaray, G., "Speciation of Beryllium, Nickel, and Vanadium in Soil Samples from Cseoel Island, Hungary," Fresenius J. Anal. Chem., Vol. 370, No. 6, pp. 768-775 (2001).

26. Rijstenbil, J.W., "Selection of Phytoplankton Species in Sulture by Gradual Salinity Changes," Neth. J. Sea Res., Vol. 22, pp. 291-300 (1988).

27. Saravanane, N., Satpathy, K.K., Nair, K.V.K., and Durairaj, G., "Preliminary Observations on the Recovery of Tropical Phytoplankton after Entrainment," $J$. Therm. Boil., Vol. 23, No. 2, pp. 91-97 (1998).

28. Sasikumar, N., Azariah, J., and Nair K.V.K., "Changes in the Composition of a Tropical Marine Fouling Community at a Power Plant Discharge," Biofouling, Vol. 6, pp. 221-234 (1993).

29. Shanon, C.E. and Weaver, W., The Mathematical Theory of Communication. University of Illinois Press, Urbana (1963).

30. Shaw P.T., "The Intrusion of Water Masses into the Sea Southwest of Taiwan," J. Geophys. Res., Vol. 94, 1821318226 (1989).

31. Yamaji, I., Illustrations of the Marine Plankton of Japan, Hoikusha Publishing Co. Ltd., Osaka (1991). 